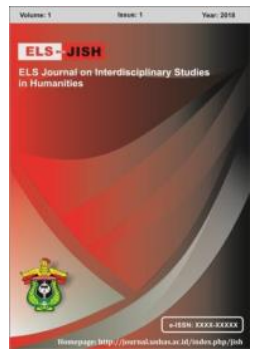

ELS-JISH

ELS Journal on Interdisciplinary Studies on Humanities

Volume 3 Issue 4, 2020

ISSN (print) : 2621-0843

ISSN (online) : 2621-0835

Homepage : http://journal.unhas.ac.id/index.php/jish

\title{
Non-Verbal Communication by Autistic Children
}

\author{
Irga Safira ${ }^{1}$, Rahmadsyah Rangkuti $^{2}$, Ely Hayati Nasution ${ }^{3}$, Yulianus \\ Harefa $^{4}$
}

1irgasafira19@gmail.com

\begin{abstract}
This paper entitled 'Non-Verbal Communication by Autistic Children' was conducted with the aim to find out the components of kinesics as a part of nonverbal communication expressed by autistic children when interacting with their teachers at SLB ABC Taman Pendidikan Islam. Beside that this study also intended to know the meanings of those kinesics components expressed by autistic children when interacting with their teachers. This research used a descriptive qualitative approach by applying kinesics theory by Ray Birdwhistell. The data collection techniques were conducted by using non-participant observation techniques and documentation. The documents used to support this study were in the form of photographs and video recorder that showed the communication done by the autistic children with their teachers during the learning process in the class. The results showed that although autistic children cannot interact clearly through verbal communication, they can express their desires through non verbal communication. They can communicate by expressing it through facial expressions, eye contact, body movement, posture and touch. The meaning of the non-verbal communication expressed by each autistic child has a different meaning. This study also intended to give worthy contribution to all people who want to understand the non-verbal communication of autistic children.
\end{abstract}

Keywords: Autistic Children, Non-Verbal Communication, Kinesics

How to cite: Safira, I. et al. (2020). Non-Verbal Communication by Autistic Children. ELS Journal on Interdisciplinary Studies in Humanities, 3(4), 492-505. DOI: https://doi.org/10.34050/elsjish.v3i4.8065

\section{Introduction}

Humans always carry out social interactions with each other because they cannot live alone. Communication is very important for people to help them interact with other humans and to convey their ideas. The definition of communication in terminology means the delivery of statements by someone to others as a consequence of social relations (Sunardi, 2007). The understanding of communication here emphasizes communication as a tool of social relations and as a consequence of humans as social beings..

Quill cited in (Gardner, 1999) states that communication is a dynamic process in which there is an encoding process of the messenger and decoding of the recipient of the message. There is an exchange of information and 
delivery of feelings (involving emotions); there is a certain goal and there is an idea. From the notion of communication, it can be said that communication always involves two individuals or more and most importantly is the desire, intent, message or purpose of the sender of the message can be received and understood by the recipient of the message.

Communication is an important aspect of expressing feelings, ideas, desires, and needs. To communicate, a tool is needed. The main tool in communication is language (Jordan \& Powell, 1995). It means that both communication and language cannot be separated. Language is needed for communication, involving either verbal or non-verbal language. It is known that in human's communication, there are two essential aspects, they are verbal communication and non-verbal communication (Borg, 2009).

The verbal communication is concerned with the spoken language to convey messages, whilst, the nonverbal communication is the process of communicating messages through the use of facial language, the use of touch and space, gestures, tone of voice and so on. Nonverbal communication is often used to describe feelings and emotions. If a message received through a verbal system does not show the strength of the message, then the nonverbal signs are received as supporters.

The concept of nonverbal communication as a signal in communication is clearly found in the research conducted by Mehrabian cited in (Borg, 2009) who argues that firstly, 55\% of the meaning in each message comes from visual body language (movements, attitudes, facial expressions) and secondly, $38 \%$ of the meaning in each message comes from a nonverbal element of words (vowels ) or in other words; the way in which the words are spoken through the tone, pattern, and speed of sound, and thirdly, $7 \%$ of the meaning comes from the actual words (contents).

Based on Mehrabian's research, it can be concluded that half of the communication used is using nonverbal communication to convey messages. Nonverbal communication is a message in the form of nonverbal expression, without a word or language or commonly known as the silent language. Its function is to complement and even replace the existence of verbal communication whether through facial expressions, hand movements, and so on.

Nowadays, humans frequently use the non-verbal communication rather than the verbal communication in interacting with others. They become more comfortable in using non-verbal communication to express their feelings and emotions to others. A real example seen in today's era with advancing technology is that gadgets make people less use of verbal language. They prefer to use emoticons to express their feelings. They spend more time with gadgets than spending time with people around them. This includes in a small family that they rarely communicate with each other when they are together. They do not realize that they have become an autistic sufferer.

The use of non-verbal communication itself is generally used by autistic children because of their lack of language that makes them rarely use the verbal communication (Tammasse, Jumraini, \& Rahman, 2019). As Cadette 
said, "Children with autism spectrum disorder (ASD) have limited communication skills. Most of them having difficulty with communication and language, as well as social interactions" (Cadette et al., 2016). They have special uniqueness that is different from other normal human, namely the ability to respond to something if it gets a normal imbalance directly and also has a high stimulus response in themselves during the learning process, such as clapping and flapping hands.

Some other autistic children naturally use other people's body language as additional instructions to help them learn and understand words (Prevezer et al., 2009). Alshurman and Alsreaa also added that when autistic children are trained non-verbal communication skills at an early age, they become more capable to express their emotions and feelings in more than one way such as through body gestures and pointing (Alshurman \& Alsreaa, 2015). It is important to learn more about the non-verbal communication expressed by autistic children in showing their desires. Because the autistic children cannot communicate verbally like other normal children.

They have a developmental disorder in their growth that is generally seen in the first three years of their lives. This developmental disorder called as Autism Spectrum Disorder (ASD). The Autism Spectrum Disorder experienced by children with autism affects the way they communicate, interact socially, imagination and attitude which is a collection of syndromes that interfere with nerves. That is why this study discussed about the non verbal communication that expressed by children with autism when they interact with others.

This study is in line with the previous studies conducted by Rukmini Rasyid with the results of research that basically autistic children are children who have a developmental disorders that can show diverse nonverbal behaviors, such as facial expressions, eye contact, body movements and haptic (Rasyid, 2014). They can expressed it well as a form of a sense of desire to interact with us. And the meaning of nonverbal communication behavior that occurs in the autistic children is very different from nonverbal communication behavior in other normal children.

This research is expected to give beneficial significance for the readers either theoretical or practical significance. Theoretically, it will give worthy contribution to all people who want to understand the non-verbal communication of autistic children. And practically, it will Intensify the people's concern about the non-verbal communication and the meaning expressing by autistic children.

\section{Method}

In this study the researcher using the descriptive qualitative which was done by doing field work. According to Nana Syaodih Sukmadinata, qualitative descriptive research is intended to describe existing phenomena, both naturals and human engineering, which pay more attention to the characteristics, quality, and interrelationships between activities (Sukmadinata, 2011). In this study, the researcher used descriptive qualitative design to analyse the data, in which to understand the forms of kinesics found in autistic children and about the meaning of those kinesics forms through observation and documentation. This research was also accompanied by using a case study method. Case study is a 
research method that uses a variety of data sources that can be used to examine, describe and explain systematically various aspects of individuals, groups, programs, organizations or events.

The subject of the research became the source of the data consisting of:

a. Five autistic children at Sekolah Luar Biasa ABC Taman Pendidikan Islam who were selected as the data source in this analysis. The five autistic children are classified as autistic children who can be trained, which is in accordance with the object of this research. The autistic children are S.W (17 year old boy), M.A.M (11 year old boy), F.Y.S (11 year old boy),U.I.A (15 year old girl), and A.A.N (14 year old boy).

b. The teacher who gave the information about the autistic child in order to help the researcher in analysing this research.

The data took from the component of non verbal communication related to kinesics that expressed by autistic children in Sekolah Luar Biasa ABC Taman Pendidikan Islam. The data obtained then analyzed and described by applying the theory of kinesics proposed by Ray L. Birdwhistell.

Kinesics is the study of non-verbal communication. The word kinesics is derived from the Greek word kinsis, with meaning motion. Kinesics encompasses nonverbal communicatory messages, such as posture, gestures, and facial expressions, as a method to convey information and emotion. The term kinesics was officially established by anthropologist Ray L. Birdwhistell in 1952. Birdwhistell states that as little as $30 \%$ of information transferred during conversation is from spoken words (Birdwhistell, 1970). Much of what is conveyed is through non-linguistic body movement and facial expressions.

Birdwhistell lists seven assumptions that form the basis of his theory, namely:

1. Like many other natural events, there is no bodily movement or a human statement without carrying a specific meaning in the context of his appearance.

2. As with other aspects of human behaviour, the actual appearance of the body, its movements and expression on the face are a pattern which is the subject of systematic review.

3. As well as the possibility that the understanding of gestures can be explained in part biologically, but in other ways systematically the body movements of members of a particular society can also be explained as a function of the social system owned by a particular group.

4. Real bodily activities such as the sound wave activity that is heard, systematically influences the behaviour of other people who are members of a group.

5. Likewise, there are still other ways that a person exhibits as behaviour so that it can be explained through an investigation of the communication function. 
6. An understanding is actually drawn from the functions of one's behaviour and what it does.

7. Some biological systems and life experiences that are specific to each person will contribute to the kinesics system they have.

Birdwhistell suggests that every limb such as the face (including smiles and eyesight), hands, head, legs and even the body as a whole can be used as symbolic signals. Because we live, all our limbs are always moving (Birdwhistell, 1979). In the study of nonverbal communication, Birdwhistell propose several components of kinesics communication, they are facial expression, eye contact, body movement, posture and haptic (Birdwhistell, 1979).

Facial expression refers to movements or certain conditions of facial muscles that facilitate nonverbal communication of some thoughts, emotions, or behaviour. When someone expresses his face, these facial expressions do not occur separately, but it occurs in groups simultaneously because parts of the face such as the mouth, lips, nose, eyes, eyebrows, chin, etc., contribute to each other to form an expression. In addition, there are also other features that accompany them such as nodding your head or shaking your head and changing postures and movements.

The study of eye contact is also called as oculesics. It deals with studies of eye movement, eye behaviour, eye gaze, and eye-related non-verbal communication. Eye contact is one of the best ways to build positive relationships and trust each other, just like when we make eye contact with someone who was talking to us, it will make him feeling be appreciated because we pay attention to him. Eye contact can indicate degree of attention or interest, influence attitude change or persuasion, regulate interaction, communicate emotion, define power and status, and has a central role in managing impressions of others.

Body movement is the voluntary or involuntary movements of body parts such as the hands, feet, legs and shoulders, which can strengthen or contradict with what is verbally communicated. Body movement is a strong indicator of how you feel, such as nervousness, excitement, and anxiety. For example, when we win a race, we accidentally raise our hands up by clenching our fingers like we are holding something while laughing, screaming and smiling. That thing hinted that we were very happy at that time.

Posture refers to the way people hold themselves back while working, at social gatherings, or in public places. Posture communicates a lot of information about you. The way you sit, stand, slump, or slouch gives information about your gender, status, self-image, attitude, and emotional state. For example, sitting with your head in your hand often shows that you feel low, whereas sitting with your feet on the desk may be interpreted by others as a sign of your feeling of superiority. A slouching body posture can show submissiveness or fatigue while one's erection signifies dominance or an energetic state of mind.

Haptic studies the sense of touch. Touch, or haptic understanding, is very important for human development because it provides information about the 
surface and texture, and is vital in conveying physical intimacy in various types of relationships. As Guerrero cited in (Montagu, 1984) said that touch is very important for human development; it allows children to reach their full social and intellectual potential and helps them become comfortable with intimacy. So the connection of the theory of kinesics with this research is because autistic children are more dominant using non verbal communication than verbal communication to convey and receive messages. But the non-verbal communication they use has meaning which is a substitute for verbal communication.

The data of this study was obtained from various sources, with using various data collection techniques that were carried out continuously until the data were saturated. In accordance with the characteristics of the data needed in this study, the data collection techniques carried out by using observation and documentation. The researcher also conducted interviews with the teachers but only as the second opinion. Because of the condition of autistic students who have limitations, so the researcher observed and conducted interviews with teachers who did know the development of their students every day, so that the data obtained was indeed in accordance with the purpose of this study.

In this study, the researcher conducted direct observations at Sekolah Luar Biasa ABC Taman Pendidikan Islam. Observation is divided into two types, namely participant observation and non-participant observation. In this case, the researcher acts as a non-participant observation where the researcher directly observes the autistic child in communicating with the teacher and his environment, starting from the teaching and learning process to completion.

The documents that are used to support this study in the form of photographs and video recorder that show the communication carried out by the autistic child during the learning process in the class. In writing this analysis, the data has been collected through an observation and documentation from the communication carried out by the autistic child in SLB ABC Taman Pendidikan Islam.

\section{Findings}

While conducting the research in the location, researcher observed five autistic children who tend to use non-verbal communication in communicating with their teacher during the learning process. The kinesics components and the meaning expressed by autistic children during the learning processed are very diverse, such as facial expression, eye contact, body movement, posture, and haptic as explained in the followings:

\subsection{Kinesics Components and The Meaning Expressed by S.W}

S.W is an autistic child with a hyperactive nonverbal type. He is not easily distracted when someone else is watching him. He used to learn based on his mood. If he feels happy then he will study well as Mrs. R.H said: "S.W is a child who has difficulty in speaking and learning depends on mood. But he will be very focused on his studies if he is in a good mood. He has a good motor 
nerves and he is an active child." The kinesics components and the meaning expressed by S.W can be seen in the following explanation:

The facial expression that found by S.W are first occurred when the teacher obeyed what he wanted. He gave the responds to his teacher by expressing it through his lips curl upwards and his eyes focused on the object that he wanted. This facial expression means that he was feeling glad. Second happened when he heard a loud and noisy sounds like when he heard the sound of his teacher being angry, the sound of people screaming, and the sound of people crying. Instantaneously his facial expression changed with a slightly twitching eyebrow expression with eyes looking up, clenched teeth, mouth closed accompanied by a soft growl. This facial expression means that he was feeling uncomfortable.

The eye contact that found by S.W are first happened when the lesson was started. The teacher began to prepare all the equipment for learning such as taking her pen and writing the lesson material in a book, and at that moment his eyes focused on seeing his teacher and the eyes also moved in following every movement made by his teacher. This eye contact means that he was in a good mood to study. Second occurred while he was studying. His eyes focused on the task he was working on and occasionally his eyes often glanced at his teacher. This eye contact means that he wanted to make sure about what he was doing was correct or not.

The body movement that found by S.W are first occurred when he has finished praying to start his studies. He wanted to tell something to his teacher, but he expressed it by his body movement, he grabbed the bag in his chair then directed the bag to his teacher. This body movement means that he wanted to start the lesson immediately. Second happened when the teacher asked whether he wanted to pee or not, he answered the teacher's question trough his body movement with moved his hand up and down. This body movement means that he wanted to say "No". He didn't want to do what his teacher asked.

The posture that found by S.W are first happenend when he started the lesson. He showed it by his posture with sitting in an upright position facing the teacher, folding his hands on the table and with his eyes focused on the teacher or on the book on his desk. This posture means that he wanted to learn. His mood was good to take lessons at that time. Second occurred when the teacher did not want to follow what he wanted. He changed his sitting position from sitting to the front facing his teacher to the position on the left beside his teacher. This posture means that he was sulking. He was upset because his teacher didn't want to follow what he wanted.

The haptic that found by S.W are first occurred when his teacher asked him to say hello to his teacher. He responded by pulling and grasping his teacher's right hand and then pointing it to his forehead. This haptic means that it is a response he gave when he was asked to say greetings like "asssalamualaikum". And when he heard the greeting "good morning", he would respond it by shaking hands with his teacher. Second happened when his teacher called his name, he patted slowly on his forehead and both cheeks using his fingers, and gently patted his chest with his hands. This haptic means 
that he wanted to say "Yes, I am" or "Yes, I am here" when his teacher called his name. And it was also a response that he understands or realizes that his name is called by his teacher.

\subsection{Kinesics Components and The Meaning Expressed by M.A.M}

M.A.M is a passive autistic child. He still cannot talk yet, just like S.W that has been explained earlier. Although he cannot speak yet, he can express his feelings by communicating his feeling through non-verbal communication. The kinesics components and the meaning expressed by M.A.M can be seen in the following explanation:

The facial expression that found by M.A.M are first occurred when when he was praised by researcher, the response he gave could be seen from his facial expression. His lips widened up with the head down and the eyes down. This facial expression means that he felt ashamed. Second happened when when his name called by his teacher. He gave the response with the expression of his eyebrows rised up, his lips opened and then closed again, and his eyes focused on his teacher. This facial expression means that he wanted say "What".

The eye contact that found by M.A.M are first occurred during the learning process. He focused on seeing his teacher explaining what he would learn that day. This eye contact means that he was in the good mood to learn. Second happened while he learned his eyes focused on the task that he did and occasionally glanced at his teacher's eyes. This eye contact means that he wanted to make sure about what he was doing was correct. The body movement that found by M.A.M are first occurred when he was asked whether the food he ate was delicious or not, he responded it by nodding his head and eyes staring at the person who invited him to talk. This body movement means that he wanted to say "Yes". Second happened when he had not yet started his lesson. His body moved toward that object and then he reached out his hand to be able to reach the object. This body movement means that he was curious at something.

The posture that found by M.A.M are first happenend when he started to learn the subject that he loved. Sitting up straight facing his teacher, his lips smiled and slightly opened and his eyes focused on the object that he had on the table. This posture means that he was happy on learning his favourite subject. Second occured when he was studying. He showed a posture by sitting with his head bent to the table and hands resting his chin on the table.This posture means that he was feeling bored. The haptic that found by M.A.M are first occured when he got praise from researcher. The response he gave was through his hands holding his hair with his head bowed and smiling. This haptic means that he was feeling shame. Second happned when he had managed to do something asked by his teacher. He usually had a high five with his teacher. This haptic means that he wanted to express his pleasure because he was able to do the things that his teacher asked. he did not understand something, he expressed it with his left hand scratching his head. This haptic means that he wanted to tell that he didn't know what to do. 


\subsection{Kinesics Components and The Meaning Expressed by F.Y.S}

F.Y.S is an active autistic child who has a deficiency in speaking just like S.W and M.A.M, he tends to use non-verbal communication when communicating with others. But sometimes he still wants to say one word in conveying what he wants. And he has good motor skills. The kinesics components and the meaning expressed by F.Y.S can be seen in the following explanation:

The facial expression that found by F.Y.S are first occurred when when he was writing, because he always made a mistake on doing it. He gave a response to his teacher with the opened mouth, the head looked up, the eyebrows moving up and down slowly, and the eyes looking at the teacher. This facial expression means that he wanted to ask to his teacher whether something that he wrote was correct or wrong. Second happened when he cannot do the right things on studying with his teacher which made his teacher became angry with him. The response that he made can be seen from his facial expression; flat facial expression, mouth closed, eyes closed, and head bowed. This facial expression means that he was afraid. It is the facial expression he made when he feels scared.

The eye contact that found by F.Y.S are first occurred during his study. His eyes focused on the task he was doing and occasionally his eyes glanced at his teacher who was accompanied by a slight movement of the body backwards. This eye contact means that he wanted to ask to his teacher whether something that he wrote was correct or wrong. Second occurred when the teacher was writing about what they would be learned by him at that time. His eyes focused on seeing his teacher while the teacher was writing and explaining the lesson that he would learn. This eye contact means that he was earnestly paying attention to the lesson that was conveyed by his teacher.

The body movement that found by F.Y.S are first happened when the teacher called his name, the response he gave was by moving his head up, furrowing eyebrows, and opening and closing the lips, which all of the movements were repeated three times as if he wanted to say something but his voice was not heard. This body movement means that he wanted to say "What". Second occured when his teacher told him to take a drinking bottle in his bag, but he found it difficult to find. He opened his mouth and moved his head up, then he shooked his head slightly. This body movement means that he wanted to say "I don't know." He could not find the bottle that his teacher asked for. Third occured when his teacher praised him as a smart child, spontaneously he immediately sat leaning back, looked away with a smile, then covered his mouth with both hands. This body movement means that he became uncomfortable and embarrassed because he was said "smart" by his teacher.

The posture that found by F.Y.S are first occured in the body position that he was shown when he was studying in class. He sat in a position facing his teacher, both hands placed on the table with his left hand held while his right hand held the pencil and with his eyes focused on the teacher. This posture means that he was seriously in studying. It is his body posture when he was serious in learning. Second happened when he was always wrong in writing 
letters that were instructed by his teacher. He changed his sitting position from sitting upright facing his teacher turns into sitting by leaning on the chair, lips opened and with a blank stare at his teacher. This posture means that it is his posture when he gave up doing things that were told by his teacher.

The haptic that found by F.Y.S are first happened while he was learning to write but everything he wrote was wrong. A moment later he touched his right cheek with his finger and brushed his left cheek with his right hand, and leaned his body to the chair. This haptic means that he gave up in writing the letter on his book. Second occurred when he was right to do the task given by his teacher writing the letter " $\mathrm{J}$ " in his book, he got a high five with his teacher. This haptic means that he wanted to express his pleasure because he was able to do the things that his teacher asked. Third happened while he was writing letters in his book. He leaned his body on the bench, his hands touched his cheeks then rubbed his eyebrows and then his hands covered his face and then released it again. This haptic means that he wanted to take a rest for a while when he was studying.

\subsection{Kinesics Components and The Meaning Expressed by U.I.A}

U.I.A is a passive autistic child who has motor skills that are still relatively weak. She is almost similar to S.W, F.Y.S and M.A.M who have deficiencies in speaking and tend to use non-verbal communication more often when communicating with others. However, she wanted to say one word in conveying what she wanted. The kinesics components and the meaning expressed by U.I.A can be seen in the following explanation:

The facial expression that found by U.I.A are first occurred when she started the lesson with her teacher. She showed a response through that facial expression with a broad smiley face, pulled up lips and cheeks, slightly opened mouth, risen up eyebrows, and eyes focused on the book on the table. This facial expression means that she was happy to follow the lessons given by her teacher. Second happened when the teacher says the word "smart" to herself, she responded trough her facial expression like the expression of lips that were opened and curved upward and teeth were slightly visible. This facial expression means that she felt very happy. A form of pleasure when she heard a praise for herself.

The eye contact that found by U.I.A happened when she realized that the researcher was watching her. The response she gave was a quick glance then looked away at strangers. This eye contact means that She did not like being watched or seen by people who she does not know. The body movement that found by U.I.A are first occurred when she was interested in something. The response she gave was she immediately stretched out her hands and grabbed the object she wanted, and accompanied by repetition of the word "want" which she said verbally. This body movement means that she wanted to show to her teacher that she wanted to get that thing. Second occurred when she started to study. She shook her body and her eyes looked at the table as her teacher pulled out objects that would be used for her to study at the time. This body movement means that it is her expression of her pleasure when studying. 
The posture that found by U.I.A are first happened to indicate her position of sitting while learning, namely sitting with both hands on the table and with her eyes focused on the object (book) on the table. This posture means that she was in a good mood to study. Second occurred while studying, she sat with her back leaning on the chair while holding her lips and gazing down. This posture means that she was tired and she wanted to take a rest. The haptic that found by U.I.A are first occurred while she was studying. Suddenly she touched her lips and moved her body backwards to lean back on the chair. This haptic means that she wanted to rest for a while during the learning process. Second occurred when she was hard to answer a question gave by her teacher. Then she showed an expression through her body by leaning to the back of the chair and scratching her head. This haptic means that she was feeling confused.

\subsection{Kinesics Components and The Meaning Expressed by A.A.N}

A.A.N is a hyperactive autistic child who also has good motor skills. He often expresses what he wants through nonverbal communication and also added by one or two words that complement his communication. Although sometimes the meaning of the word that he was talking about doesn't make sense. The kinesics components and the meaning expressed by A.A.N can be seen in the following explanation:

The facial expression that found by A.A.N are first occurred when he was curious about the strangers in his class. He was looking at the stranger (researcher), raising and lowering his eyebrows, and lips widen upwards. This facial expression means that he wanted to be acquainted with researcher. Second occurred when he got praise from his teacher. He shows his pleasure through the expression on his face; mouth widely opened and up, eyebrows went up, brow slightly frowned, head went up, and eyes widened. This facial expression means that he was feeling very happy. Third occurred when he was scolded by his teacher. He shed his tears, widened his lips down, and went eyes down. This facial expression means that he was feeling so sad. He did not like being scolded and snapped at.

The eye contact that found by A.A.N are first happened when he started the lesson. His eyes focused on the book on the table and looked at his teacher. This eye contact means that he was in the good mood to learn. Second happened while his eyes focused on the task he was working on and occasionally his eyes often glanced at his teacher in order to make sure that he could continue the task or not. This eye contact means that he wanted to make sure what he was doing was correct. The body movement that found by A.A.N are first occurred when he got tired of writing. He expressed it through his body movement-his hand stopped writing and put the pencil on the table, his eyes looked left and right, and his body leaned at the back of the chair. This body movement means that he wanted to take a rest. Second happened when the teacher was not paying attention. He put the lobe (hat) he used on his teacher's head, then took it back and put it back on his head. This body movement means that he wanted to play with his teacher.

The posture that found by A.A.N are first happened when he started the lesson. He was sitting in an upright position looking at his teacher. This posture 
means that he wanted to study or being in a good mood to study. Second occurred when he started to feel bored. He expressed it by showing his posture sitting with his head bent to the table and hands resting his chin on the table. This posture means that he was feeling bored. The haptic that found by A.A.N are first occurred when he saw a stranger (researcher). He was clapping his hands while looking at the researcher. This haptic means that he wanted to attract the researcher's attention. Second happened when he was not feeling good. He was biting his hands. This haptic means that he was angry.

\section{Discussion}

A.A.N is a hyperactive autistic child who also has good motor skills. He often expresses what he wants through nonverbal communication and also added by one or two words that complement his communication. Although sometimes the meaning of the word that he was talking about doesn't make sense. The kinesics components and the meaning expressed by A.A.N can be seen in the following explanation:

The facial expression that found by A.A.N are first occurred when he was curious about the strangers in his class. He was looking at the stranger (researcher), raising and lowering his eyebrows, and lips widen upwards. This facial expression means that he wanted to be acquainted with researcher. Second occurred when he got praise from his teacher. He shows his pleasure through the expression on his face; mouth widely opened and up, eyebrows went up, brow slightly frowned, head went up, and eyes widened. This facial expression means that he was feeling very happy. Third occurred when he was scolded by his teacher. He shed his tears, widened his lips down, and went eyes down. This facial expression means that he was feeling so sad. He did not like being scolded and snapped at.

The eye contact that found by A.A.N are first happened when he started the lesson. His eyes focused on the book on the table and looked at his teacher. This eye contact means that he was in the good mood to learn. Second happened while his eyes focused on the task he was working on and occasionally his eyes often glanced at his teacher in order to make sure that he could continue the task or not. This eye contact means that he wanted to make sure what he was doing was correct. The body movement that found by A.A.N are first occurred when he got tired of writing. He expressed it through his body movement-his hand stopped writing and put the pencil on the table, his eyes looked left and right, and his body leaned at the back of the chair. This body movement means that he wanted to take a rest. Second happened when the teacher was not paying attention. He put the lobe (hat) he used on his teacher's head, then took it back and put it back on his head. This body movement means that he wanted to play with his teacher.

The posture that found by A.A.N are first happened when he started the lesson. He was sitting in an upright position looking at his teacher. This posture means that he wanted to study or being in a good mood to study. Second occurred when he started to feel bored. He expressed it by showing his posture sitting with his head bent to the table and hands resting his chin on the table. This posture means that he was feeling bored. The haptic that found by A.A.N 
are first occurred when he saw a stranger (researcher). He was clapping his hands while looking at the researcher. This haptic means that he wanted to attract the researcher's attention. Second happened when he was not feeling good. He was biting his hands. This haptic means that he was angry.

\section{Conclusion}

Based on the analysis of the research about non-verbal communication expressed by autistic children of SLB ABC Taman Pendidikan Islam, the researcher concludes that:

Although autistic children cannot interact clearly through verbal communication, they can express their desires through non verbal communication related to kinesics. They can communicate well with their teacher through facial expressions, eye contact, body movement, posture and touch. The most dominant kinesics components that expressed by autistic children are body movement and haptic.

The meaning of those kinesics components that expressed by each autistic child has a differents meaning. This differences happened because of the differences in age and different levels of autism. For example, In the part of haptic, A.A.N made an applause when his teacher was talking with others. This kinesics components means that he was looking for attention of his teacher. While S.W also did an applause when he was able to answer the question that asked by his teacher. This kinesics components means that he was feeling happy.

Children with disabilities especially autistic children should not be shunned or discriminated against because of their limitations. However, they must be given more opportunities to communicate and interact even through non-verbal communication. Hopefully this research can change people's views about autistic children who are often seen as unable to do anything and experience obstacles in communication. They can be more sensitive or even more aware of the presence of those children, because basically all human beings are created both normal humans and those who have limitations also have the same rights.

\section{References}

Alshurman, W., \& Alsreaa, I. (2015). The Efficiency of Peer Teaching of Developing Non Verbal Communication to Children with Autism Spectrum Disorder (ASD). Journal of Education and Practice, 6(29), 33-38.

Birdwhistell, R. L. (1970). Masculinity and femininity as display. Kinesics and Context: Essays on Body Motion, 39-46.

Birdwhistell, R. L. (1979). Kinesik. KR Scherer, HG Wallbott (Hg.): Nonverbale Kommunikation: Forschungsberichte Zum Interaktionsverhalten. Weinheim, 192-202.

Borg, J. (2009). Buku pintar memahami bahasa tubuh. Terj. Abdul Hamid. Yogyakarta: THiNK.

Cadette, J. N., Wilson, C. L., Brady, M. P., Dukes, C., \& Bennett, K. D. (2016). The effectiveness of direct instruction in teaching students with autism 
Spectrum disorder to answer "wh-" questions. Journal of Autism and Developmental Disorders, 46(9), 2968-2978.

Gardner, H. (1999). Intelligence Reframed: The Theory in Practice. New York City, NY: Basic Books.

Jordan, R., \& Powell, S. (1995). Understanding and Teaching Children with Autism. Wiley.

Montagu, A. (1984). The skin, touch, and human development. Clinics in Dermatology, 2(4), 17-26.

Prevezer, W., Newson, E., Christie, P., \& Chandler, S. (2009). First Steps in Intervention with your Child with Autism: Frameworks for Communication. Jessica Kingsley Publishers.

Rasyid, R. (2014). Perilaku Komunikasi Nonverbal Anak Autis Dalam Proses Belajar di Sekolah Luar Biasa (SLB) Pembina Tingkat Provinsi Sulawesi Selatan di Kota Makassar.

Sukmadinata, N. S. (2011). Metode Penelitian dan Pendidikan. Bandung: PT Remaja Rosdakarya.

Sunardi, S. (2007). Intervensi Dini Anak Berkebutuhan Khusus. Jakarta: Departemen Pendidikan Nasional.

Tammasse, Jumraini, \& Rahman, F. (2019). Some difficulties in verbalizing English words and phrases: A case study of suspected dyslexic children. Asian EFL Journal, 26(6), 73-85. 